\title{
Does Migration Pay? Earnings effects from geographic mobility following job displacement ${ }^{\star}$
}

\author{
Anders Boman ${ }^{\star \star}$
}

First version: February 2007

This version: August 2007

\begin{abstract}
Displaced workers are followed for ten years in order to analyse the earnings effects from internal migration. We utilise a large dataset containing all workers in Sweden who were involuntarily displaced from work during 1987 or 1988. Earnings effects from migration are investigated controlling for human capital, family, and labour market characteristics. Substantial gender differences in earnings effects from internal migration are found, where men in general have positive effects, while the consequences for women are negative.
\end{abstract}

JEL Classification: J31, J61, J65

Keywords: internal migration, earnings effects, job displacement

\footnotetext{
${ }^{*}$ I would like to especially thank Lennart Flood and Marcus Eliason for comments and suggestions. I also thank participants at the Labour and Public Finance workshop at the Department of Economics, Göteborg University, Sweden. Further thanks go to seminar participants at the Department of Economics, Uppsala University, Sweden, and at the XXI Annual Conference of the European Society for Population Economics, Chicago, USA

${ }^{* *}$ Department of Economics, School of Business, Economics and Law, Göteborg University, Sweden. E-mail: anders.boman@economics.gu.se
} 


\section{Introduction}

The earnings effects from job displacements have been thoroughly studied and the overall conclusion is that displaced workers suffer substantial earnings losses. ${ }^{1}$ It is therefore important to analyse what can mitigate these earnings reductions.

When a worker is displaced it is only natural that he should look for a new job and if needed we expect him to migrate. This reallocation of labour, both between jobs and geographic, is important to the labour market and the economy as a whole, but the intensity and geographic scope of this search may differ between individuals and between groups of individuals in society. Previous research has shown that nonNordic immigrants are more mobile than native Swedes following job displacement (Boman, 2006); possible reasons ranging from experiences of previous migration to tougher labour market conditions. Olli Segendorf (2005) showed that immigrants who found work had typically made a far greater effort in order to get that job than that of native counterparts.

In spite of the amount of theoretical reasoning on the effects of reallocation of labour, there is a lack of empirical research on the effects of geographic migration following job displacement. Although some post-displacement studies on US data have included migration as an explanatory variable (for instance Addison \& Portugal, 1987 or Herzog \& Schlottmann, 1995), similar studies on European data are scarce. As US residents are generally considered more mobile than Europeans (Greenwood, 1997), this paper makes an important contribution to this field of research.

\footnotetext{
${ }^{1}$ See Fallick (1996) for a review. For instance Ruhm (1991) finds that weekly earnings are about $16 \%$ lower one year after displacement. Four years after displacement, their earnings were still about $14 \%$ lower than those of the control group. Similar findings are reported by Jacobson et al (1993), where earnings reductions are found to be both large and persistent. Couch (2001) uses German data and finds no significant differences between displaced and non-displaced workers in the years prior to displacement, but large earnings reductions are found in the years after displacement. Farber et al. (1997) fins that earnings losses are substantial, even for the sub-sample of full time workers. Eliason \& Storrie (2005) analyse the effects of job displacement and find that displaced Swedish workers suffer from earnings losses, initially recover, but are more vulnerable to labour market conditions.
} 
Fallick (1996) lists four reasons for expecting displaced workers to receive lower wages: loss of job- or sector-specific human capital, loss of a high-quality match with the job, loss of industrial or union wage premiums, and loss of seniority. That human capital could be sector specific, rather than firm specific, is supported by the finding that workers displaced from Silicon Valley semi-conductor plants suffered no wage reductions if they were rehired by another high-tech firm (Ong \& Mar, 1992). The loss of sector specific human capital can be reduced by migration to a similar job in a different location, as compared to staying in the same area but changing sector. Migration could therefore be expected to counteract the above disadvantages and mitigate reductions in wages.

Post-displacement unemployment and wages depend on the search behaviour of the worker (Hammermesh, 1989). If reservation wages decline slowly with unemployment duration, the likelihood of re-employment will be lower but subsequent post-displacement wages will be higher. Thus, the initial displacement is involuntary, but the duration of unemployment and the level of wages are endogenously determined and will vary with workers' search behaviour, characteristics and mobility.

As individuals will only migrate if the expected benefits of doing so outweigh the costs (Sjaastad, 1962), migration should have a positive earnings effect, possibly with an early drop but with recovery to a higher level than prior to migration. This should be even more pronounced for displaced individuals. If they are unemployed ${ }^{2}$ and move they should be moving to a job. If they are not unemployed but move anyway, this should be motivated by a better job in the destination. Irrespective of

\footnotetext{
${ }^{2}$ Far from all displaced workers experience unemployment.
} 
pre-migration employment status, earnings should be higher in the post-migration period.

However, on the US labour market post-displacement migration has been found to increase the time of unemployment (Addison \& Portugal, 1987 and Nord \& Ting, 1991, 1992). This can be due to a lack of knowledge on the new labour market, additional search and information costs to migration and possibly also due to negative selection if migrants are mainly individuals with labour market difficulties who therefore choose to move to a new area. Pekkala and Tervo (2002) use Finnish data, finding that larger shares of movers escape unemployment. However, using instrumental variables to control for endogenous selectivity they note that the move itself does not improve employability and their conclusion is that it is not migration but differences between movers and stayers that make movers more successful in finding jobs. The effect on earnings is less clear. Nord and Ting $(1991,1992)$ find no statistically significant effect on earnings, while Borjas, Bronars and Trejo (1992) found that young workers who migrated within the US initially had lower earnings than did non-migrants in the destination area, but wages of migrants were found to catch up with non-migrants in the new location after six years. This supports the argument that individuals make decisions based on lifetime earnings and using too short a period of study will therefore miss some of the earnings increase (Greenwood, 1997). Thus, time since migration in many previous studies could well be too short to capture the positive effects from migration.

Many studies have been conducted on the economic assimilation of immigrants. ${ }^{3}$ This paper complements those studies by looking at differences in earnings for individuals who are already established on the labour market.

\footnotetext{
${ }^{3}$ See for instance Chiswick (1978), Borjas (1985, 1987, 1989) for American studies, Aguilar \& Gustafsson (1991), Gustafsson et al. (2004), Tezic (2004) for Swedish
} 
Furthermore, the earnings effects from migration could differ between natives and immigrants.

The earnings effects from internal migration following involuntary job displacement are analysed using registry data on all employees in Sweden who lost their jobs due to large downsizings or complete closures of workplaces in 1987 or 1988. Workers in our data are displaced in a period of an extremely healthy labour market, which may reduce the earnings losses. This could affect our results, but if anything we underestimate the effects from migration.

The paper is organised as follows: Section 2 presents the dataset and the constructed variables. Section 3 presents some descriptive statistics, whereas sections 4 and 5 introduce the empirical model and the results, respectively. Section 6 concludes.

\section{Sample selection and variable definitions}

Various registry data sources provide detailed information on a wide range of demographic, family, and labour market characteristics, all registered on an annual basis. In studies on displaced workers, self-reported causes of displacement are commonly used. As those are bound to be at least to some degree arbitrary (Farber, Haltiwanger \& Abraham, 1997), we instead use registry data to classify the cause of displacement.

The original data set covers all individuals in Sweden who were displaced from their jobs due to a closure or substantial cutback ${ }^{4}$ of an establishment with ten or more

\footnotetext{
${ }^{4}$ A substantial cutback is defined as a reduction of the workforce by $20 \%$ or more.
} 
employees, which occurred in 1987 or $1988 .{ }^{5}$ We follow these individuals for ten years, giving us a relatively long period of study compared to previous research.

Since retirement age in Sweden is 65 years we remove those who are older than 55 in the year of displacement. Furthermore, we also remove those younger than 25 years as they commonly migrate for educational reasons. ${ }^{6} \mathrm{We}$ also exclude 675 individuals with earnings higher than 500000 Swedish krona.

\subsection{Displacement}

Differences in economic outcomes have been found to depend on when and how you leave a dying plant (Ruhm, 1991; Huttunen, 2005). As a plant closure can be a complex process lasting for some years great care has been taken to identify so called early leavers; workers who are displaced because of the forthcoming closure, but leave early in the closing process. ${ }^{7}$ A reduction in the work force (cutback), on the other hand is considered to be quicker. Workers displace from cutbacks are defined as employees who separated from the workplace during the year of a large cutback ${ }^{8}$ in 1987 or 1988, which was not followed by a closure within two years.

Note that what is actually recorded in the data is separation, not displacement. We observe a separation of employer and employee between November $1^{\text {st }}$ in the year prior to the cutback or closure and October $31^{\text {st }}$ the following year. As these separations occurred at the same time as substantial downsizing or plant closure we interpret and treat them as displacements.

\footnotetext{
${ }^{5}$ It should be noted that individuals can be displaced as early as 1986 due to advance notice of a forthcoming closure, see section 2.1 .

${ }^{6}$ A recent survey showed that of migrants aged 18 to $25,43.6 \%$ gave education as their main reason for migration. This share then rapidly drops with age. In age groups 26 to 30 and 31 to 40, the shares are $12.3 \%$ and $0.6 \%$, respectively (Niedomysl, 2006).

${ }^{7}$ Details of the closure process and the process of compiling this data can be found in Eliason and Storrie (2004).

${ }^{8}$ In this paper, only reductions of the workforce by $20 \%$ or more are considered
} 


\subsection{Internal migration}

We can observe changes in municipality over time, but a mere change of municipality does not necessarily constitute labour market oriented migration. Municipal borders can be crossed simply in order to change size or type of your dwelling, i.e. from smaller to larger, larger to smaller or from apartment to detached house and so on. Using change in municipality of residence to define migration consequently means including an unnecessarily large number of moves that are made for non-labour market reasons.

Long-distance migration is traditionally regarded as more labour market oriented, but intra-region migration, from one side of the region to the other, can be more long-distance than cross-border migration. Thus, analysing migration based on strict geographical borders is problematic.

We use Local Labour Markets as defined by Statistics Sweden, merging the Employment Register, based on the employers' social security payments at the establishment level, and the Population Register. Local Labour Markets are constructed by using actual commuting behaviour to aggregate municipalities between which there are high levels of commuting, and borders are drawn between municipalities where commuting is very rare. ${ }^{9}$

We only look at those individuals who migrate within Sweden no later than five years after displacement. The reasons for this are twofold; firstly, migration close to displacement is more likely to be related to that displacement. Secondly, this gives us at least five years of observation after migration.

\footnotetext{
${ }^{9}$ Details of the procedures are found in Statistics Sweden (1991).
} 


\section{Descriptives}

We find that the group of individuals who migrate following job displacement generally do have the characteristics we would associate with higher mobility, see Table 1. In the year prior to displacement future migrants are younger, have fewer children, to a lesser degree live in cities, have a higher share of men and have more often experienced unemployment, but have a higher educational attainment.

Earnings increase prior to, during, and after the year of displacement, which is rather surprising. ${ }^{10}$ Apart from the fact that our period of study is in a booming economy with large wage increases in general, we look at all displaced, not a selected group, it is possible that the large effect on those most sensitive is masked by the large number of others in our study. However, we do observe a large decrease in earnings 3-5 years after displacement, which is due to macroeconomic changes.

Prior to displacement, immigrants change industry more than natives, immigrant men changing industry the most. ${ }^{11}$ After displacement immigrant men are more geographically mobile than immigrant women, but both groups change industry more often than do natives. Native women change industry the least. Bailey (2005) found that immigrants on the US labour market were significantly less likely to change industry following job displacement, arguing that this could be due to immigrants either having insufficient human capital to switch industry or that they are unwilling to lose the industry specific human capital they have accumulated.

Five years after displacement, movers have a higher share of individuals with at least some unemployment $(18,6 \%$ vs $8,6 \%)$. This contradicts the argument that

\footnotetext{
${ }^{10}$ In a study of earnings effects from displacement from closures, using a subsample of the data used in this study, Eliason \& Storrie (2006) show that compared to non-displaced workers those displaced from closures experience reductions in earnings.

${ }^{11}$ Industry is defined on a two digit SNI-level. The SNI classification is based on the NACE system of the European Union.
} 
migration should be to something better, that movers should have lower, not higher unemployment rates. On the other hand, earnings increase more over time for movers. Five years after displacement movers have on average increased their annual earnings by about $14.5 \%$, compared to two years prior to displacement. Over the same period earnings of stayers increased by about $10.8 \%$.

\section{Econometric specification}

We want to find the effect from migration ${ }^{12}\left(\delta_{\mathrm{s}}\right)$ on discounted annual earnings $\left(W_{i t}\right)$ controlling for personal and regional characteristics $\left(X_{i t}\right)$. In order to catch both long term and short term effects of migration time dummies representing time (s) since first post-displacement migration $\left(M_{i s}\right)$ are included.

$$
W_{i t}=X_{i t} \beta+M_{i s} \delta_{s}+u_{i t}
$$

Does $\delta_{s}$ capture the true effect from migration? Not if the individuals who migrate are more skilled or able and would typically have a better development of annual earnings irrespective of whether they migrate or not. Educational attainment ${ }^{13}$ is typically used as a proxy for skill or ability and therefore included in the regressions, but education is only part of individual skill. Gabriel and Schmitz (1995) find that migrants are in fact selected, having higher earnings prior to migration, even when differences in characteristics are controlled for. As a second part we therefore earnings from work in the year preceding displacement as a proxy for skill. This is in line with Hunt (2004), who argues that wage differences not explained by education

\footnotetext{
${ }^{12}$ We look only at the effects of the first post-displacement migration, as this is most closely related to the initial job displacement. Additional migration can be argued to be, at least partially, a consequence of the first migration.

${ }^{13}$ For immigrants, education obtained in the country of origin is not automatically included in the registers as it is for individuals who obtained their education as a part of the Swedish system. However, information on such education is obtained through the Population and Housing Census from 1990. Thus, if information on education is missing before 1990, but is observed in 1990, we use this information for the previous years as well, since it is reasonable to assume that the education was obtained but not recorded earlier.
} 
show differences in ability. The inclusion of these two variables measuring different part so individual skill should reduce the problem of selection on unobservables.

A non-trivial share of displaced workers has zero annual earnings at some point in time, and the distribution of zeros is not even between groups. Having no earnings is more common among women, which could be due to parental leave. ${ }^{14}$ Furthermore, immigrants have a higher share, which is most likely due to, among other things, a higher share of early retirement. ${ }^{15}$ As it is plausible that this truncation at zero earnings could affect our results we use a Tobit-model with random effects.

However, as migration is voluntary the individuals who do migrate will be those who benefit the most from doing so (Maddala, 1983). Thus, migrating individuals will benefit more than would a randomly chosen sample. Consequently, the treatment will produce greater total benefits under self-selection than under random assignment. This is a problem of self-selection into treatment (Greene, 2003) and we can expect $u_{i t}$ and $X_{i t}$ to be correlated.

Together this would lead us to the use of a so called double hurdle model. However, Flood and Gråsjö (2001) show that the double hurdle model is sensitive to misspecifications of the index function and that a Tobit I model will produce smaller bias if the index equation is unknown. As the migration decision is largely based on unobserved and non-quantifiable variables, we cannot reasonably argue that the index equation is known.

\footnotetext{
${ }^{14}$ The Swedish rules for compensation for parental leave are very generous, and parental leave for one full year is not uncommon.

${ }^{15}$ Foreign-born have higher rates of early retirement, and there are several reasons to expect immigrants to be more prone to early retirement (Gustafsson, 2004). Early retirement is related to health status, as you have to be considered unfit to work. Many immigrants are refugees from war, with traumatic experiences that affect their health in a negative way. Other immigrants are labour migrants, who have generally worked many hours, which may also have affected their health negatively. As a third reason, many immigrants have had long spells of unemployment, which could have adverse effects on mental health.
} 
A similar argument can be made against using instrumental variables. Since the decision to migrate is largely based on factors unobservable to the researcher, instruments for migration are usually very weak. Using weak instruments entails the risk of estimates being even more biased and inconsistent (Bound, Jaeger \& Baker, 1995; Angrist \& Krueger, 1999)

Thus, although risking biased results, the alternatives are no better and we use a panel Tobit I model with random effects.

\section{Results}

Estimation results show expected coefficients for most included variables ${ }^{16}$ as can be seen in table 2. Migration generally brings no or negative earnings effects in the first years following migration. This is in line with previous research. Interestingly, the negative effects seem to disappear five or six years after migration, followed by positive effects in the last years for which we have observations. This is an interesting finding on its own, indicating that migrants will most likely benefit from migration in the long run, rather than suffer economic losses, as has been argued in previous research. However, an even more interesting pattern emerges when we split the data by gender. Focusing first on the differences in effects from migration, we see that men benefit substantially from migration, at least in the long run. Women, on the other hand, suffer economics losses in every year following migration. The difference is substantial $^{17}$, and may be due to differences in the causes for migration. Women have

\footnotetext{
${ }^{16}$ One exception is the positive effect from having no registered education. However, individuals with no registered education are generally older and it is likely that the lack of registered education is a result of missing information in registers rather than actually lacking education.

${ }^{17}$ Median discounted (1983 value) earnings for all years is slightly less than 87000 SEK (just over 72000 for women, almost 102000 for men).
} 
traditionally been considered to be tied movers to a larger extent than men, the argument being that men move for labour market reasons and their wives follow. ${ }^{18}$

There are other interesting differences between men and women as well. Men have a much more pronounced age effect and the peak is earlier, at age 40-44. Men also get a higher return to higher education, bur are more disadvantaged for being immigrants, both first and second generation, than are women. Women are more disadvantaged for having young children, but this will at least partly be due to gender differences in parental leave.

We also analyse the differences between immigrants and natives by running the regressions separately for Nordic and non-Nordic immigrants. The migration effects remain for Nordic immigrants. Non-Nordic immigrants have almost no significant effects from migration. What effects we find are negative for both men and women.

\section{Conclusion}

We have used an unusually long panel to analyse the earnings effects from internal migration of involuntarily displaced workers. In general, the short term effects are negative, which is in agreement with previous research. In the long run, however, effects appear to be positive.

The effects from migration differ between groups. Men typically benefit substantially from migration, whereas women have even negative effects. This could be because women, to a larger extent, are tied movers. Another reason could be that women value non-monetary rewards to migration higher than do men. We must assume that individuals only migrate if they consider themselves gaining from it, incurring a positive total effect, and that women are equally good as men at predicting

\footnotetext{
${ }^{18}$ The negative effects are smaller ,but still remain, if we look only at women who are not married. As previously mentioned we are unfortunately unable to identify cohabitation, which could be a reason for the remaining negative effect.
} 
the future. Thus, if monetary returns to migration are nonexistent, there must be other unobserved, gains for women, in order for migration to occur. On what these benefits are, we can only speculate.

Nordic immigrants have effects similar to native Swedes, while non-Nordic immigrants appear to have no significant earnings effects from migration.

Although studies of earnings effects in general, and from migration in particular, are plagued by the risk of biased results, the main finding of this paper should be unaffected by this. We use both educational attainment and observed earnings differences prior to displacement to capture differences in skills. Even if the estimated effects are biased in spite of this, the difference between men and women should not be affected. 
Table 1: Descriptive statistics

\begin{tabular}{lcccc}
\hline \hline & \multicolumn{2}{c}{ Movers } & \multicolumn{3}{c}{ Stayers } \\
\hline Age & \multicolumn{2}{c}{ Std. Dev. } & Mean & \multicolumn{2}{c}{ Std. Dev. } \\
Male & 37,843 & 8,413 & 33,520 & 7,957 \\
Children: 0-6 years & 0,530 & 0,499 & 0,551 & 0,497 \\
Children: 7-15 & 0,251 & 0,434 & 0,232 & 0,422 \\
Children: 16-17 & 0,332 & 0,471 & 0,187 & 0,390 \\
Married & 0,098 & 0,297 & 0,047 & 0,212 \\
Unmarried & 0,534 & 0,499 & 0,357 & 0,479 \\
Divorced & 0,347 & 0,476 & 0,506 & 0,500 \\
Widowed & 0,111 & 0,314 & 0,132 & 0,338 \\
Education: None registered & 0,008 & 0,091 & 0,006 & 0,076 \\
Education: Compulsory & 0,146 & 0,353 & 0,153 & 0,360 \\
Education: High School & 0,260 & 0,439 & 0,178 & 0,382 \\
Education: Undergraduate & 0,417 & 0,493 & 0,431 & 0,495 \\
Education: Graduate studies & 0,174 & 0,379 & 0,234 & 0,424 \\
Living in major city & 0,003 & 0,058 & 0,004 & 0,062 \\
Foreign Born & 0,516 & 0,500 & 0,404 & 0,491 \\
Second Generation Immigrant & 0,125 & 0,331 & 0,105 & 0,307 \\
Annual earnings ${ }^{1}$ & 0,169 & 0,375 & 0,157 & 0,364 \\
Job creation rate & 0,822 & 0,450 & 0,747 & 0,478 \\
Job destruction rate & 0,161 & 0,047 & 0,159 & 0,053 \\
Previous migration & 0,098 & 0,030 & 0,097 & 0,031 \\
\hline \hline All & 0,018 & 0,133 & 0,300 & 0,458 \\
\hline
\end{tabular}

All values are as of one year prior to displacement

${ }^{1}$ In 100000 Swedish krona, 1983 value 
Table 2: Effects on earnings

\begin{tabular}{|c|c|c|c|c|c|c|c|c|c|}
\hline & \multicolumn{3}{|c|}{ all } & \multicolumn{3}{|c|}{ Men } & \multicolumn{3}{|c|}{ Women } \\
\hline & Coef. & & Std. Err. & Coef. & & Std. Err. & Coef. & & Std. Err. \\
\hline Age: $25-29$ & $-0,050$ & 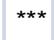 & 0,001 & $-0,062$ & $\star \star \star$ & 0,002 & $-0,031$ & $\star \star \star \star$ & 0,002 \\
\hline Age: $30-34$ & $-0,022$ & $\star \star \star$ & 0,001 & $-0,023$ & $\star \star \star$ & 0,001 & $-0,016$ & 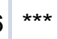 & 0,001 \\
\hline Age: $35-39$ & ref. & & & ref. & & & ref. & & \\
\hline Age: $40-44$ & 0,016 & $\star \star \star *$ & 0,001 & 0,008 & $\star \star \star$ & 0,001 & 0,022 & 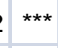 & 0,001 \\
\hline Age: $45-49$ & 0,009 & 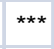 & 0,001 & $-0,006$ & $\star \star \star$ & 0,002 & 0,023 & $\star \star \star \star$ & 0,001 \\
\hline Age: $50-54$ & $-0,029$ & $\star \star \star$ & 0,001 & $-0,050$ & $\star \star \star \star ~$ & 0,002 & $-0,006$ & $\star \star \star \star ~$ & 0,002 \\
\hline Age: $55-59$ & $-0,102$ & $\star \star \star$ & 0,002 & $-0,131$ & $\star \star \star$ & 0,003 & $-0,067$ & 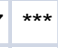 & 0,002 \\
\hline Age: $>60$ & $-0,311$ & $\star \star \star$ & 0,002 & $-0,379$ & $\star \star \star \star ~$ & 0,004 & $-0,229$ & 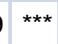 & 0,003 \\
\hline Male & 0,074 & 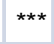 & 0,002 & - & & - & - & & - \\
\hline Children: 0-6 years & $-0,074$ & $\star \star \star$ & 0,001 & $-0,011$ & $\star \star \star \star ~$ & 0,001 & $-0,160$ & $\star \star \star \star$ & 0,001 \\
\hline Children: 7-15 & 0,024 & $\star \star \star *$ & 0,001 & 0,017 & $\star \star \star$ & 0,001 & 0,021 & $\star \star \star$ & 0,001 \\
\hline Children: 16-17 & 0,016 & $\star \star \star *$ & 0,001 & 0,012 & $\star \star \star$ & 0,001 & 0,018 & 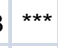 & 0,001 \\
\hline Married & ref. & & & ref. & & & ref. & & \\
\hline Unmarried & $-0,019$ & 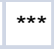 & 0,001 & $-0,038$ & $\star \star \star$ & 0,002 & 0,018 & 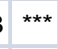 & 0,001 \\
\hline Divorced & $-0,009$ & $\star \star \star$ & 0,001 & $-0,033$ & $\star \star \star \star ~$ & 0,002 & 0,022 & 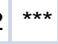 & 0,001 \\
\hline Widow ed & $-0,019$ & $\star \star \star$ & 0,004 & $-0,039$ & $\star \star \star \star$ & 0,008 & $-0,030$ & $\star \star \star \star ~$ & 0,004 \\
\hline Education: None & 0,072 & $\star \star \star$ & 0,001 & 0,082 & $\star \star \star$ & 0,002 & 0,056 & 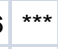 & 0,002 \\
\hline Education: Compulsory & ref. & & & ref. & & & ref. & & \\
\hline Education: High School & 0,038 & $\star \star \star$ & 0,001 & 0,035 & $\star \star \star \star ~$ & 0,002 & 0,035 & 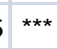 & 0,001 \\
\hline Education: Undergraduate & 0,199 & $\star \star \star$ & 0,002 & 0,236 & $\star \star \star$ & 0,003 & 0,165 & 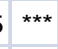 & 0,002 \\
\hline Education: Graduate studies & 0,452 & $\star \star \star$ & 0,007 & 0,466 & 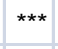 & 0,010 & 0,431 & 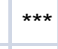 & 0,011 \\
\hline Years since displacement & 0,019 & $\star \star \star$ & 0,001 & 0,022 & $\star \star \star \star ~$ & 0,002 & 0,011 & 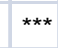 & 0,002 \\
\hline Living in major city & 0,043 & $\star \star \star$ & 0,001 & 0,048 & $\star \star \star \star ~$ & 0,002 & 0,041 & $\star \star \star$ & 0,001 \\
\hline Foreign Born & $-0,096$ & $\star \star \star *$ & 0,002 & $-0,122$ & $\star \star \star$ & 0,003 & $-0,058$ & $\star \star \star \star$ & 0,002 \\
\hline Second Generation Immigrant & $-0,015$ & $\star \star \star$ & 0,002 & $-0,018$ & $\star \star \star$ & 0,003 & $-0,010$ & 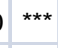 & 0,002 \\
\hline Pre-displacement earnings ${ }^{1}$ & 0,654 & $\star \star \star$ & 0,002 & 0,684 & $\star \star \star \star ~$ & 0,002 & 0,548 & 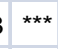 & 0,002 \\
\hline Job creation rate & 0,032 & $\star \star \star$ & 0,007 & 0,030 & $\star \star \star \star$ & 0,010 & 0,033 & $\star \star \star$ & 0,008 \\
\hline Job destruction rate & $-0,001$ & & 0,007 & $-0,005$ & & 0,011 & 0,025 & 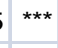 & 0,008 \\
\hline Years since migration: 0 & $-0,003$ & & 0,003 & 0,011 & $\star \star \star \star ~$ & 0,004 & $-0,026$ & $\star \star \star \star$ & 0,003 \\
\hline Years since migration: 1 & $-0,014$ & $\star \star \star$ & 0,003 & $-0,001$ & & 0,004 & $-0,035$ & 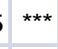 & 0,003 \\
\hline Years since migration: 2 & $-0,011$ & $\star \star \star$ & 0,003 & 0,005 & & 0,004 & $-0,036$ & 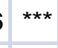 & 0,003 \\
\hline Years since migration: 3 & $-0,006$ & ** & 0,003 & 0,014 & $\star \star \star$ & 0,004 & $-0,033$ & 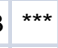 & 0,003 \\
\hline Years since migration: 4 & $-0,007$ & ** & 0,003 & 0,019 & $\star \star \star$ & 0,004 & $-0,037$ & 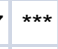 & 0,003 \\
\hline Years since migration: 5 & $-0,003$ & & 0,003 & 0,026 & $\star \star \star$ & 0,004 & $-0,037$ & 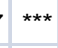 & 0,003 \\
\hline Years since migration: 6 & 0,002 & & 0,003 & 0,035 & $\star \star \star \star ~$ & 0,004 & $-0,034$ & 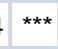 & 0,003 \\
\hline Years since migration: 7 & 0,007 & ** & 0,003 & 0,049 & $\star \star \star$ & 0,005 & $-0,038$ & 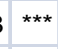 & 0,004 \\
\hline Years since migration: 8 & 0,006 & * & 0,003 & 0,044 & $\star \star \star$ & 0,005 & $-0,034$ & $\star \star \star \star$ & 0,004 \\
\hline Years since migration: 9 & 0,010 & ** & 0,004 & 0,057 & $\star \star \star$ & 0,006 & $-0,042$ & 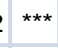 & 0,005 \\
\hline Constant & $-0,308$ & 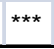 & 0,003 & $-0,305$ & $\star \star \star \star ~$ & 0,005 & $-0,172$ & 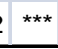 & 0,004 \\
\hline Controlled for industry ${ }^{2}$ & \multicolumn{3}{|c|}{ yes } & \multicolumn{3}{|c|}{ yes } & \multicolumn{3}{|c|}{ yes } \\
\hline Controlled for year & \multicolumn{3}{|c|}{ yes } & \multicolumn{3}{|c|}{ yes } & \multicolumn{3}{|c|}{ yes } \\
\hline /sigma_u & 0,265 & & 0,001 & 0,297 & & 0,001 & 0,210 & & 0,001 \\
\hline /sigma_e & 0,265 & & 0,000 & 0,298 & & 0,000 & 0,216 & & 0,000 \\
\hline rho & 0,500 & & 0,001 & 0,497 & & 0,001 & 0,486 & & 0,001 \\
\hline Number of individuals & \multicolumn{3}{|c|}{175665} & \multicolumn{3}{|c|}{93606} & \multicolumn{3}{|c|}{82059} \\
\hline Number of observations & \multicolumn{3}{|c|}{1725907} & \multicolumn{3}{|c|}{915889} & \multicolumn{3}{|c|}{810018} \\
\hline \multicolumn{10}{|c|}{ Dependent variable is annual earnings, divided by 100000 for computational reasons } \\
\hline \multicolumn{4}{|l|}{${ }^{1}$ Annual earnings divided by 100000} & & & & & & \\
\hline \multicolumn{7}{|c|}{2 Industry $w$ here the individual $w$ as employed in the year prior to displacement } & & & \\
\hline
\end{tabular}


Table 3: Effects on earnings for the immigrant subsample

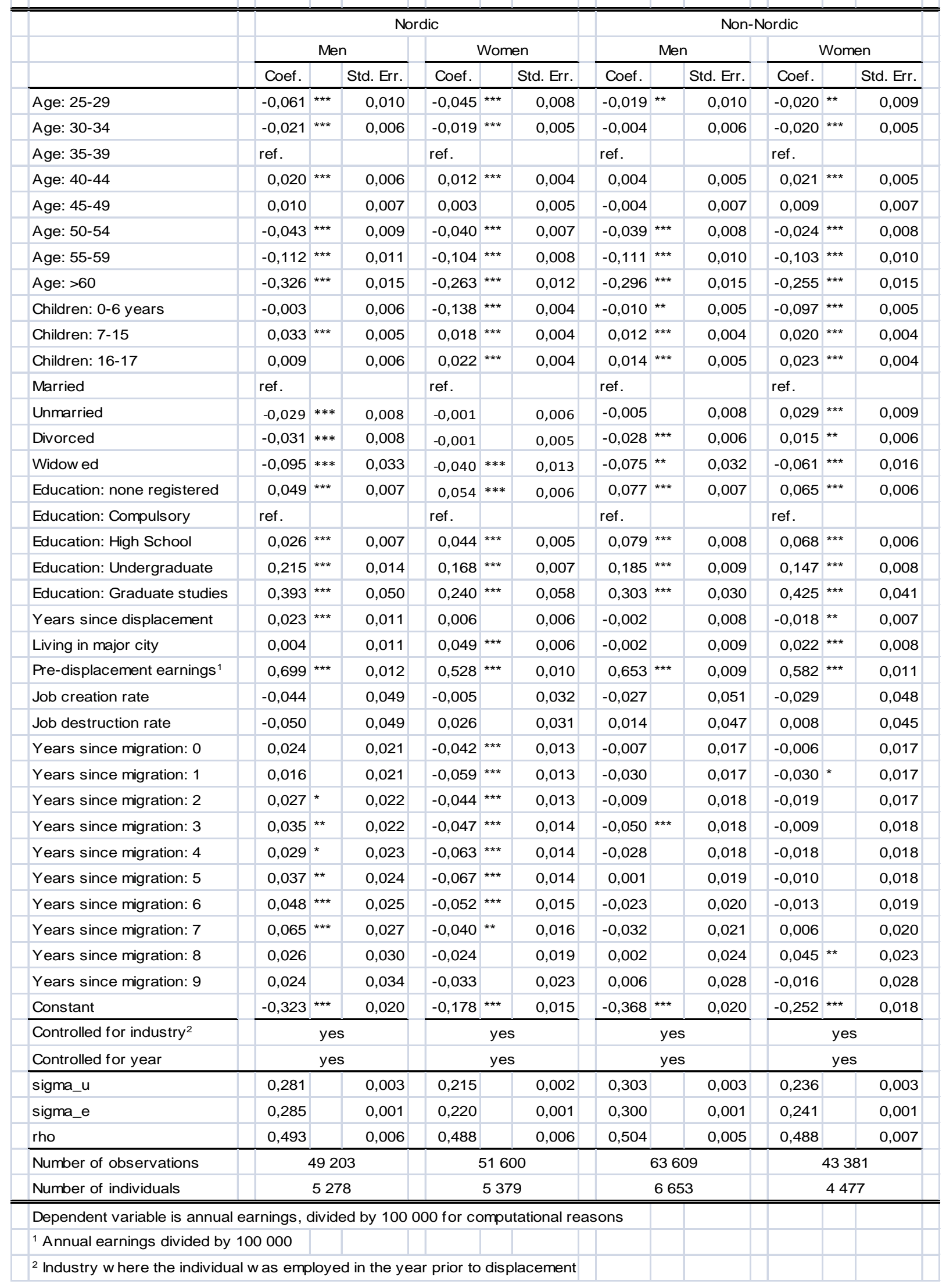




\section{References}

Addison, Hohn T. \& Portugal, Pedro (1987) The Effect of Advance Notice of Plant Closings on Unemployment, Industrial and Labor Relations Review, Vol. 41, No. 1

Aguilar \& Gustafsson (1991) The Earnings Assimilation of Immigrants, Labour, Vol. 5 , No. 2

Angrist, Joshua D, Krueger Alan B (1999) Empirical Strategies in Labor Economics, in Ashelfelter O. \& Card, D. (eds) Handbook of Labor Economics, Elsevier Science, Amsterdam, pp 1277-1366

Bailey, Linda (2005) Do Immigrants Adapt Better to Job Loss? Evidence from Displaced Workers, mimeo

Boman, Anders (2006) Internal Migration of Natives and Immigrants Following Job Displacement, Working Paper in Economics No. 192, Department of Economics, Göteborg University

Borjas (1985) Assimilation, Changes in Cohort Quality, and the Earnings of Immigrants, Journal of Labor Economics, Vol. 3, No. 4,

Borjas (1987) Self-Selection and the Earnings of immigrants, The American Economic Review, Vol. 77, No. 4

Borjas (1989) Immigrant and Emigrant Earnings: a Longitudinal Study, Economic Inquiry, Vol. XXVII, January

Borjas, George J., Bronars, Stephen G., Trejo, Stephen J. (1992a) Assimilation and the Earnings of Young Internal Migrants, The Review of Economics and Statistics, Vol. 74, No. 1

Bound, John; Jaeger, David A.; Baker, Regina M (1995) Problems with Instrumental Variables Estimation When the Correlation Between the Instruments and the Endogenous Explanatory Variable is Weak, Journal of the American Statistical Association, Vol. 90, No. 430

Chiswick (1978) The Effect of Americanization on the Earnings of Foreign-born Men, Journal of Political Economy, vol. 86, No. 5

Couch, Kenneth A. (2001) Earnings Losses and Unemployment of Displaced Workers in Germany, Industrial and Labor Relations Review, Vol. 54, No. 3

Eliason, Marcus \& Storrie, Donald (2004) The Echo of Job Displacement, Working Paper in Economics No. 135, Department of Economics, Göteborg University

Eliason, Marcus \& Storrie, Donald (2005) Lasting or Latent Scars? Swedish evidence on the long-term effects of job displacement, Journal of Labor Economics, Vol. 24, No. 4

Fallick, Bruce C. (1996) A Review of the Recent Empirical Literature on Displaced Workers, Industrial and Labor Relations Review, Vol. 50, No. 1

Farber, Henry S.; Haltiwanger, John; Abraham, Katharine G.(1997) The Changing Face of Job Loss in the United States, 1981-1995, Brookings Papers on Economic Activity, Microeconomics, Vol. 1997

Flood, Lennart \& Gråsjö, Urban (2001) A Monte Carlo simulation study of Tobit models, Applied Economics Letters, Vol. 8

Gabriel, Paul E. \& Schmitz, Susanne (1995) Favorable Self-Selection and the Internal Migration of Young White Males in the United States, The Journal of Human Resources, Vol. 30, No. 3

Greene, William (2003) Econometric Analysis, fifth edition, New York University, Prentice Hall 
Greenwood, Michael J. (1997) Internal Migration in Developed Countries, in Rosenzweig \& Stark (eds.), Handbook of Population and Family Economics, North-Holland, Amsterdam.

Gustafsson, Björn(2004) Early retirement among immigrants in Sweden 1981 to 1999, mimeo

Hammermesh, Daniel S. (1989) What Do We Know About Worker Displacemnts in the U.S.? Industiral Relations, Vol. 28, No.1

Herzog, Henry W. \& Schlottmann, Alan M. (1995) Worker Displacement and JobSearch: A Regional analysis of Structural Impediments to Reemployment, Journal of Regional Science, Vol. 35, No. 4

Hunt, Jennifer (2004) Are Migrants More skilled than non-migrants? Repeat, Return, and Same-Employer Migrants, NBER Working Paper 10633

Huttunen, Kristiina (2005) Empirical Studies on Labour Demand, Wages and Job Displacement, Doctoral Dissertation, University of Helsinki

Jacobson, Louis S., LaLonde, Robert J., Sullivan, Daniel G. (1993) Earnings Losses of Displaced Workers, The American Economic Review, Vol. 83, No. 4.

Niedomysl, Thomas (2006) Migration and Place Attractiveness, Doctoral Thesis, Uppsala University, Sweden

Nord, Stephen \& Ting Yuan (1991) The Impact of Advance Notice of Plant Closings on Earnings and the Probability of Unemployment, Industrial and Labor Relations Review, Vol. 44, No. 4

Nord, Stephen \& Ting Yuan (1992) The Impact of Advance Notice: A Rejoinder, Industrial and Labor Relations Review, Vol. 45, No. 4

Olli Segendorf, Å. (2005) Job Search Strategies and Wage Effects for Immigrants, Doctoral Thesis, Swedish Institute for Social Research, Stockholm University, Sweden

Ong Paul M., Don Mar (1992) Post-Layoff Earnings among Semiconductor Workers, Industrial and Labor Relations Review, Vol. 45, No. 2

Pekkala, Sari \& Tervo, Hannu (2002) Unemployment and Migration: Does Moving Help? Scandinavian Journal of Economics, Vol. 104, No. 4

Ruhm, Christopher J. (1991) Are Workers Permanently Scarred by Job Displacements? The American Economic Review, Vol. 81, No. 1

Statistics Sweden (1991) Lokala arbetsmarknader och förvärvsregioner: Nya geografiska indelningar för regionala analyser. Information om arbetsmarknaden, Statistics Sweden.

Tezic, Kerem (2004) Essays on Immigrants' Economic Integration, Doctoral thesis, Department of Economics, Gothenburg University, Sweden 